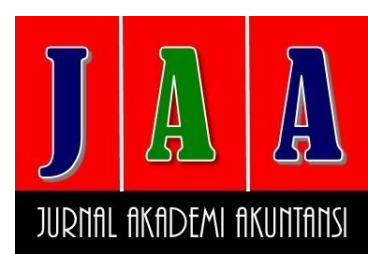

Website:

ejournal.umm.ac.id/index.php/jaa

Afiliasi:

1,2Fakultas Ekonomi, Universitas Internasional Batam, Indonesia

*Correspondence:

anita.lec@uib.ac.id

DOI: $10.22219 /$ jaa.v4i2.18188

Sitasi:

Anita, \& Lim, L. (2021). Tanggung Jawab Sosial Dan Risiko Sistematis: Efek Moderasi Dari Fleksibilitas Keuangan Dan Investasi Penelitian Dan Pengembangan. Jurnal Akademi Akuntansi, 4(2), 162-185.

Proses Artikel

Diajukan:

26 September 2021

Direviu:

30 September 2021

Direvisi:

14 November 2021

Diterima:

26 November 2021

Diterbitkan:

30 November 2021

\author{
Alamat Kantor: \\ Jurusan Akuntansi Universitas \\ Muhammadiyah Malang \\ Gedung Kuliah Bersama 2 \\ Lantai 3. \\ Jalan Raya Tlogomas 246, \\ Malang, Jawa Timur, \\ Indonesia
}

P-ISSN: 2715-1964

E-ISSN: 2654-8321
Tipe Artikel: Paper Penelitian

\section{TANGGUNG JAWAB SOSIAL DAN RISIKO SISTEMATIS: EFEK MODERASI DARI FLEKSIBILITAS KEUANGAN DAN INVESTASI PENELITIAN DAN PENGEMBANGAN}

\author{
Anita $^{1 *}$, Lisa Lim ${ }^{2}$
}

\section{ABSTRACT}

The study is conducted with the aim of examining the effect of corporate social responsibility on systematic risk in companies listed on the IDX for the period of 2016-2020. This study adds financial flexibility and research and development investment as moderators which are still remain unexplored in Indonesia. This research is expected to be able to make investors consider social responsibility as a factor in making investment decisions. The data taken are stock prices, annual reports and sustainability reports which are secondary data. Data collection using purposive sampling method with certain criteria so that the number of samples in this study amounted to 43 companies. In testing the hypothesis using panel data regression analysis techniques with eviews. The results of the regression analysis show that the existence of corporate social responsibility has a significant positive effect on systematic risk. The moderating variable of financial flexibility does not affect the relationship between CSR and systematic risk. Then the research and development investment variables weaken the relationship between CSR and systematic risk. Therefore, management is expected to pay attention to $R \& D$ investment in making CSR policies. This study explains that $R \& D$ investment is one of the important roles in company sustainability.

KEYWORDS: Corporate Social Responsibility; Financial Flexibility; Research and Development Investment; Systematic Risk; Sustainability Report.

\section{ABSTRAK}

Penelitian dilakukan dengan tujuan untuk menguji pengaruh tanggung jawab sosial terhadap risiko sistematis pada perusahaan terdaftar di BEI periode 2016-2020. Penelitian ini menambahkan fleksibilitas keuangan dan investasi penelitian dan pengembangan sebagai pemoderasi yang masih belum diteliti di Indonesia. Variabel kontrol pada penelitian ini terdiri dari return of asset, return of equity, ukuran perusahaan, dividen per saham, dividend payout ratio, dan tata kelola perusahaan. Diharapkan dengan penelitian ini, investor dapat menjadikan tanggung jawab sosial sebagai faktor pertimbangan pengambilan keputusan dalam berinvestasi. Data yang diambil berupa harga saham, laporan tahunan, dan laporan keberlanjutan yang merupakan data sekunder. Pengumpulan data menggunakan metode purposive sampling dengan kriteria tertentu sehingga jumlah sampel dalam penelitian ini sebesar 43 perusahaan. Dalam pengujian hipotesis menggunakan teknik analisis regresi data panel dengan eviews. Hasil analisis regresi menunjukkan bahwa adanya tanggung jawab sosial memberikan pengaruh signifikan positif terhadap risiko sistematis. Variabel moderasi fleksibilitas keuangan tidak mempengaruhi hubungan CSR dan risiko sistematis. Hasil

(C) $2021 \mathrm{jaa}$. This is an open access article under the CC BY SA license (https://creativecommons.org/licenses/by-sa/4.0/) http://ejournal.umm.ac.id/index.php/jaa 
penelitian membuktikan bahwa variabel investasi penelitian dan pengembangan memperlemah hubungan CSR dan risiko sistematis. Oleh karena itu, manajemen diharapkan dapat memperhatikan investasi R\&D dalam membuat kebijakan CSR. Penelitian ini menjelaskan bahwa investasi $R \& D$ merupakan salah satu peran penting dalam keberlanjutan perusahaan.

KATA KUNCI: Fleksibilitas Keuangan; Laporan Keberlanjutan; Investasi Penelitian Dan Pengembangan; Risiko Sistematis; Tanggung Jawab Sosial.

\section{PENDAHULUAN}

Dalam melakukan investasi, risiko menjadi salah satu pertimbangan penting investor dalam mengambil keputusan. Investor berinvestasi dengan tujuan untuk mendapat imbalan (return) yang maksimal dengan nilai risiko yang minimum. Menurut Puspitaningtyas (2017) menjelaskan bahwa hubungan antara return dan risiko adalah positif dan linier yang artinya jika return suatu investasi yang didapatkan semakin tinggi maka risiko yang dimiliki juga tinggi dan sebaliknya. Wibowo (2017) mendefinisikan bahwa risiko dapat mencerminkan faktor internal maupun eksternal perusahaan yang mempengaruhi nilai saham.

Secara umum, risiko terbagi menjadi dua yaitu risiko sistematis dan risiko tidak sistematis. Risiko tidak sistematis merupakan risiko yang dapat dihilangkan melalui diversifikasi portofolio dan dipengaruhi oleh faktor internal (Paramitasari, 2014). Kemudian risiko sistematis merupakan risiko yang tidak dapat dihindari dan dipengaruhi oleh faktor eksternal (Darmawati, 2015).

Para investor akan lebih tertarik melakukan investasi dalam pasar modal daripada pasar uang seperti deposito karena mengharapkan keuntungan yang lebih besar (Paramitasari, 2014). Dalam mengelola investasi keuangan yang berhubungan dengan pasar modal terdapat risiko pasar atau yang disebut dengan risiko sistematis. Perubahan pasar kini menjadi faktor yang dapat mempengaruhi imbalan yang didapatkan dalam investasi (Rahmawati, 2015). Ketika melakukan investasi, investor akan melakukan analisa kinerja saham terlebih dahulu. Jika kinerja saham perusahaan tersebut positif maka investor akan mendapatkan keuntungan dan sebaliknya. Oleh karena itu, investor memerlukan informasi yang relevan yang dapat mendeskripsikan kinerja saham dari perusahaan tersebut.

Sebagian besar penelitian menggunakan kinerja akuntansi seperti ROA, ROE, dan kinerja pasar (Tobin'q) sebagai proksi kinerja keuangan perusahaan (Agustin et al., 2013; Arsal, 2021; Rohmawati \& Shenurti, 2020; Rosikah et al., 2018). Adapun penelitian yang dilakukan oleh Utami dan Darmawan (2019) menggunakan elemen ROA, ROE, DER, EPS, dan MVA dalam mengukur nilai saham perusahaan. Namun kinerja keuangan perusahaan tidak hanya dapat diukur menggunakan kinerja akuntansi. Risiko sistematis juga dapat mencerminkan kinerja perusahaan (Park et al., 2017). Perusahaan yang memiliki risiko sistematis tinggi mencerminkan kinerja perusahaan tersebut kurang efektif. Penelitian ini akan dilakukan dengan pengukuran yaitu risiko sistematis perusahaan.

Pada awal tahun 2020 adanya penyakit menular Coronavirus Disease of 2019 (Covid-19) membawakan dampak ekonomi yang besar secara global. Rizwan et al. (2020) memproyeksikan ekonomi secara global mengalami penurunan sebesar 3\% dari produk domestik bruto (PDB) rill tahun 2020. Untuk memperlambat penyebaran virus, masyarakat diharapkan dapat mengurangi kegiatan bersosialisasi dan mengurangi mobilitas (Tambunan, 2020). Adanya kebijakan Pembatasan Sosial Berskala Besar (PSBB) yang dikeluarkan pemerintah menyebabkan perusahaan mengalami kesulitan bertahan dimasa pandemi. 
Perdagangan pasar modal merasakan dampak yang signifikan akibat Covid-19. Penurunan signifikan pada Indeks Harga Saham (IHSG) di Bursa Efek Indonesia (BEI) dicerminkan saat terpaparnya kasus positif di Indonesia.

Gambar 1.

Grafik IHSG

2017-2021

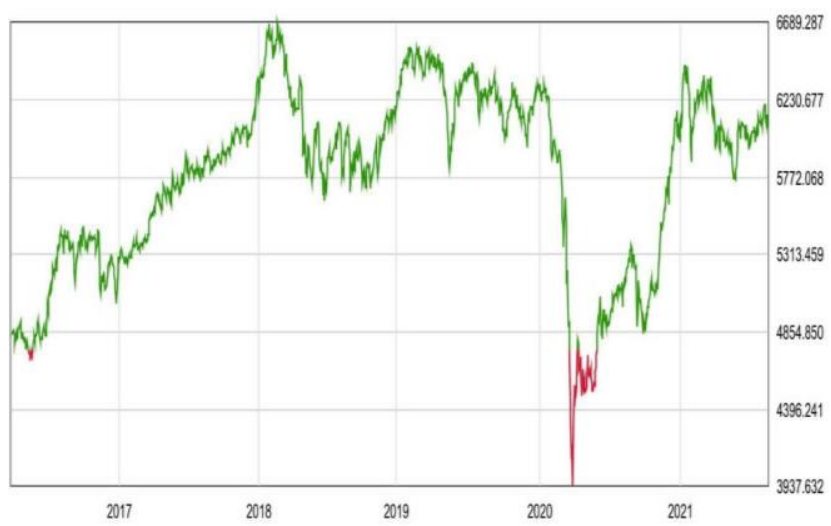

Sumber: IDX (2021)

Dari grafik dapat dilihat, indeks di pasar modal Indonesia bergerak fluktuatif sejak awal Maret 2020. Dalam 5 tahun terakhir IHSG mencapai titik terendah yaitu pada tahun 2020. Menurut Tambunan (2020), salah satu penyebab IHSG turun diakibatkan oleh banyaknya investor yang melakukan aksi jual saham. Kondisi pandemi membuat para investor perlu melakukan adaptasi dalam kegiatan berinvestasi (Santoso \& Erstiawan, 2021). Investor perlu menyaring, menganalisis, dan menyusun kembali portofolio yang dimiliki. Investor juga perlu melakukan analisis fundamental dan teknikal untuk mendapatkan tingkat pengembalian tinggi dengan tingkat risiko rendah pada kondisi pandemi ini. Darmayanti et al. (2021) melakukan penelitian yang menjelaskan bahwa adanya pengaruh pandemi Covid19 terhadap risiko sistematis. Kondisi pandemi ini mendorong pentingnya penelitian ini dilakukan untuk menganalisis lebih dalam faktor yang dapat mempengaruhi risiko sistematis yang diharapkan dapat membantu para investor untuk mengambil kebijakan dalam berinvestasi.

Berdasarkan teori investasi dalam Capital Asset Pricing Model (CAPM), risiko sistematis mendefinisikan risiko sebagai beta (Nguyen et al., 2020). Beta saham menunjukkan sensitivitas imbalan saham terhadap perubahan imbalan pasar. Terdapat beberapa perdebatan yang berbeda dalam penggunaan indeks saham yang tepat sebagai proksi pasar saham untuk pengukuran beta. Chabachib (2020) menggunakan beberapa indeks saham dalam pengukuran beta seperti indeks return LQ-45, SRI-KEHATI, PEFINDO-25, BISNIS-27, IDX-30 dan KOMPAS-100.

Beberapa penelitian menghitung beta menggunakan return IHSG (Andriani, 2010; Eduarnus, 2001; Taliawo \& Atahau, 2007). Adapun penelitian yang dilakukan oleh $\underline{\text { Sartono }}$ dan Zulaihati (1998) menjelaskan bahwa IHSG memiliki kelemahan dan tidak cukup mencerminkan kondisi pasar yang sebenarnya. Penelitiannya menjelaskan bahwa indeks LQ45 sebagai proksi lebih baik yang dapat mencerminkan kondisi pasar. Pada penelitian yang dilakukan Basu dan Rizzuto (1995) di Amerika Serikat memiliki pendapat yang berbeda di mana indeks S\&P 500 tidak dapat mewakili perubahan pasar saham Amerika Serikat sebenarnya. Dari penelitian yang dilakukan oleh Chabachib (2020); Lestari dan Candraningrat (2013) menyimpulkan bahwa proksi return pasar menggunakan indeks LQ45 maupun indeks IHSG tidak memiliki perbedaan yang signifikan. Penelitian ini akan 
menggunakan return IHSG pada BEI sebagai proksi return pasar dalam menghitung nilai beta.

Pada tahun 2007 telah dilaksanakan konferensi UN Global Compact dengan tujuan agar pelaku bisnis dalam kegiatan operasional perusahaan dapat memperhatikan lingkungan

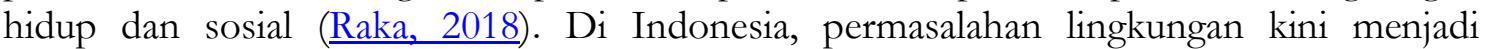
perhatian oleh para investor, konsumen, dan pemerintah (Hidayat et al., 2020). Terdapat beberapa perusahaan yang masih belum memperhatikan dampak lingkungan dan sosial yang ditimbulkan dari praktik bisnis. Seperti pada kasus perusahaan PT Bukit Asam Tbk yang menyebabkan sungai keruh dari kegiatan pertambangan (Globalnews.net, 2018). Adapun kerusakan ekosistem pantai serta sungai dikarenakan oleh aktivitas tambang PT Aneka Tambang Tbk (Prabowo, 2021).

Kepedulian terhadap tanggung jawab sosial perusahaan kini menjadi peran penting dalam operasional perusahaan (Park et al., 2017). Corporate Social Responsibility (CSR) merupakan salah satu alternatif yang mendorong perusahaan dalam pengambilan keputusan operasional. Tidak hanya memperhatikan dari sisi faktor keuangan namun juga perlu didasari oleh kondisi lingkungan kini dan pada masa depan (Tunggal, 2014). Beberapa perusahaan di Indonesia menyajikan tanggung jawab sosial tersebut dalam laporan yang mencerminkan kontribusi yang telah dilakukan perusahaan dalam aktivitas operasional dengan pengelolaan lingkungan, keselamatan kerja, dan masyarakat.

Park et al. (2017) menjelaskan bahwa perusahaan perlu menunjukkan komitmennya dalam menerapkan tanggung jawab sosial kepada para pemangku kepentingan, seperti karyawan, konsumen, pemasok, dan lain-lain. Menurut data KPMG (2017) membuktikan bahwa adanya peningkatan perusahaan dalam pengungkapan CSR secara sukarela. Menurut Kiryanto et al. (2021) perusahaan yang melakukan pengungkapan CSR akan mendapatkan respon positif dari masyarakat dan pemangku kepentingan. Pengungkapan tanggung jawab sosial dinilai dapat meningkatkan kepercayaan investor, kinerja ekonomi yang unggul, dan memberi sinyal positif dalam pasar modal (Albuquerque et al., 2017; Eriandani \& Wijaya, 2021). Oleh karena itu, penyajian CSR atau CSR disclosure menjadi salah satu cara untuk mengurangi risiko dan meningkatkan kinerja keuangan perusahaan.

Dengan menyajikan CSR akan memberikan nama baik pada perusahaan tersebut sehingga para investor ataupun stakeholder dapat menilai melalui tanggung jawab sosial perusahaan terhadap lingkungan (Djoutsa et al., 2020). Selain itu, konsumen akan lebih tertarik pada perusahaan yang telah melakukan kontribusi terhadap masyarakat maupun lingkungan. Hal tersebut akan berdampak pada peningkatan penjualan pada perusahaan dan meningkatkan keberlangsungan suatu perusahaan (Wulandari \& Erna, 2013).

Selain itu, dengan adanya penyakit virus Covid-19 ini membawa keadaan darurat bagi kesehatan masyarakat. Kondisi pandemi Covid-19 memiliki kolerasi dengan konsep triple bottom line dalam CSR yaitu people, profit, dan planet. Di mana pemasok hewan liar yang

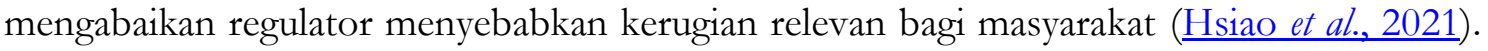
Hal tersebut menyebabkan masyarakat luas menghadapi risiko yang dapat mengancam nyawa serta kesehatan individu sosial. Maka dari itu, risiko akibat kejadian tidak terduga ini perlu dipertimbangkan dalam operasional perusahaan. Jika suatu perusahaan sebelumnya JAA memiliki langkah penghindaran risiko, ketika menghadapi kondisi pandemi, perusahaan dapat merepons dengan tepat sehingga dapat menghindari krisis. Dengan latar belakang 4.2 Covid-19, penelitian ini dilakukan untuk membuktikan apakah kinerja CSR dapat menjadi ketahanan perusahaan terhadap risiko sistematis. Pentingnya penelitian ini dilakukan agar 
dapat menjadi referensi bagi perusahaan untuk meningkatkan penilaian risiko. Begitu pula untuk pengambilan keputusan tepat bagi investor.

Penyajian laporan mengenai kinerja sosial dan lingkungan menjadi peran penting untuk mengurangi risiko perusahaan. Tidak hanya melalui kinerja keuangan, para pemangku kepentingan dan investor juga melihat kinerja sosial dan lingkungan sebagai salah satu pertimbangan. Menurut hasil penelitian yang dilakukan oleh Albuquerque et al. (2017), Cai et al. (2016), Darmawati (2015), Djoutsa et al. (2020), Eriandani dan Wijaya (2021) membuktikan bahwa CSR memberikan pengaruh negatif terhadap risiko sistematis. Bertolak belakang dengan penelitian Afifah dan Syafruddin (2021) di Indonesia yang menggambarkan pengaruh positif antara CSR dengan risiko sistematis. Adapun hasil penelitian yang berbeda yaitu penelitian yang dilakukan oleh Hassouna dan Salem (2021), Jung et al. (2018), Park et al. (2017) menjelaskan bahwa CSR tidak berpengaruh terhadap risiko sistematis. Paragina dan Leon (2020), Silalahi et al. (2020) menyimpulkan tidak adanya pengaruh CSR terhadap risiko sistematis di Indonesia. Dari beberapa penelitian di atas masih terdapat banyak hasil yang berbeda dan tidak konsisten.

Dalam pengukuran CSR, Park et al. (2017) menggunakan database MSCI ESG yang fokus pada isu komunitas, tata kelola, lingkungan, hubungan karyawan, hak asasi manusia, dan produk sebagai dimensi tanggung jawab sosial. Sedangkan Eriandani dan Wijaya (2021) melihat dari pengungkapan kinerja sosial dan lingkungan pada laporan tahunan perusahaan. Penelitian ini mengukur tanggung jawab sosial menggunakan indeks Global Reporting Initiative (GRI). Peneliti melakukan analisis pengungkapan indeks GRI G4 yang diambil dari laporan keberlanjutan perusahaan (Ariyani, 2016; Darmawati, 2015).

Berbeda dengan penelitian sebelumnya Albuquerque et al. (2017); Cai et al. (2016); Devie et al. (2019); Djoutsa et al. (2020); Matsumura et al. (2014); dan Xue et al. (2017), penelitian ini menguji kembali pengaruh tanggung jawab sosial terhadap risiko sistematis dengan menambah variabel investasi penelitian dan pengembangan (research and development) serta variabel fleksibilitas keuangan sebagai variabel moderasi (Guo et al., 2020). Hasil penelitian yang dilakukan Guo et al. (2020) menjelaskan bahwa fleksibilitas keuangan memperlemah hubungan negatif antara CSR dan risiko sistematis. Namun investasi penelitian dan pengembangan tidak berdampak pada hubungan CSR pada risiko sistematis. Penelitian ini akan menguji kembali dengan penambahan dua variabel moderasi dengan sampel perusahaan di Indonesia (2016-2020) yang berbeda dengan penelitian yang telah diuji Guo et al. (2020) yang menggunakan sampel perusahaan di Negara China.

Kontribusi teori dari penelitian ini adalah memperkaya implikasi teori pemangku kepentingan dan teori kontinjensi. Kemudian, penelitian yang dilakukan dapat memberikan informasi luas bagi investor untuk pengambilan keputusan yang tepat dalam investasi pasar modal terutama dengan mempertimbangkan pergerakan pasar modal pada situasi pandemi covid-19. Selain itu, juga dapat sebagai antisipasi bagi perusahaan dalam menghadapi guncangan ekonomi. Hasil penelitian ini akan menjawab tiga pertanyaan penelitian: (1) Apakah CSR berpengaruh signifikan terhadap risiko perusahaan? (2) Apakah fleksibilitas keuangan memperlemah pengaruh CSR terhadap risiko sistematis? (3) Apakah R\&D Investment memperlemah pengaruh CSR terhadap risiko sistematis? Penelitian ini memberikan pemahaman lebih lanjut dan mengeksplorasi hubungan antara CSR terhadap risiko perusahaan.

TINJAUAN LITERATUR DAN PENGEMBANGAN HIPOTESIS

\section{Teori pemangku kepentingan}


Teori pemangku kepentingan mendorong perusahaan untuk bertanggung jawab atas semua pemangku kepentingan dan tidak hanya pemegang saham (Donaldson \& Preston, 1995). Menurut Freeman (1994), pemangku kepentingan terdiri dari dalam maupun luar perusahaan seperti karyawan, pelanggan, pemasok, masyarakat, dan pemegang saham. Inti dari teori ini supaya manajer perusahaan dapat memaksimalkan kekayaan semua pemangku kepentingan. Sebagai contohnya, jika terjadi konflik hubungan antara para pemangku kepentingan, manajer perusahaan yang menerapkan CSR dapat menyelesaikan konflik tersebut dengan baik sehingga risiko yang terjadi pada perusahaan juga akan berkurang. Dengan begitu, dapat disimpulkan apabila perusahaan berhasil mengelola hubungan dengan pemangku kepentingan secara efektif, maka akan membantu pengembangan kinerja perusahaan menjadi lebih baik.

\section{Teori contingency}

Teori contingency menjelaskan tentang efektivitas perusahaan (Katz \& Kahn, 1966). Keberlangsungan perusahaan tergantung pada kesesuaian antara struktur dan lingkungan perusahaan. Teori ini menjelaskan bahwa terdapat lebih dari satu desain atau cara untuk mencapai efektivitas. Perusahaan dapat melakukan desain pada struktur perusahaan yang lebih sesuai dengan strategi bisnisnya. Perusahaan yang menggunakan struktur yang tidak sesuai akan menurunkan kinerjanya ( $\underline{\text { schlevogt, 2002)}}$.

Begitu pula dengan implementasi CSR juga bergantung pada karakteristik industri perusahaan tersebut. Hal tersebut mengakibatkan CSR dapat memberikan dampak positif atau negatif tergantung pada apakah tindakan tersebut sesuai dengan kondisi dan faktor lainnya. Kemudian beberapa penelitian mengenai hubungan CSR dengan risiko sistematis secara bertahap muncul di bawah perspektif kontingensi. Guo et al. (2020) menjelaskan bahwa adanya pengaruh variabel moderasi seperti fleksibilitas keuangan terhadap hubungan CSR dan risiko sistematis. Adapun Zeng et al. (2020) mendeskripsikan bahwa liputan media negatif dapat memperlemah hubungan pengungkapan air terhadap risiko perusahaan. Dengan demikian, peneliti menambahkan variabel moderasi fleksibilitas keuangan dan R\&D investment untuk meningkatkan pemahaman lebih lanjut tentang hubungan CSR dan risiko sistematis perusahaan.

\section{Risiko sistematis}

Darwanis dan Andina (2013) mengungkapkan bahwa risiko merupakan salah satu kejadian yang dapat membawakan pengaruh tidak menguntungkan. Oleh karena itu, investor dalam melakukan investasi akan mengestimasi dan memprediksi risiko yang terdapat dalam suatu perusahaan melalui faktor yang mempengaruhi. Investor dan manajer investasi akan memperhatikan risiko perusahaan untuk mendapatkan return yang optimal dalam melakukan investasi suatu perusahaan (Rahmani et al., 2017).

Terdapat 2 macam risiko yaitu risiko sistematis dan risiko tidak sistematis. Risiko sistematis merupakan suatu risiko yang terdapat di pasar modal yang di mana risiko tersebut akan selalu ada dan tidak dapat dihilangkan dengan diversifikasi. Risiko tidak sistematis merupakan risiko yang disebabkan oleh karakteristik perusahaan dan tidak berhubungan dengan perubahan pasar. Risiko tersebut dapat dihilangkan serta dapat diversifikasi (Rorong et al., 2017).

JAA

Risiko sistematis atau risiko pasar ini merupakan risiko yang terjadi karena pengaruh

4.2 kejadian di luar perusahaan. Risiko tersebut dapat dipengaruhi oleh faktor luar seperti kebijakan pemerintah, tingkat bunga deposito, tingkat inflasi, nilai tukar valuta asing, dan lain-lain (Azizah, 2018). 
Nana dan Erman (2017) menjelaskan bahwa risiko sistematis dapat mempengaruhi pasar secara keseluruhan. Risiko sistematis juga disebut dengan risiko umum adalah risiko yang timbul melalui faktor fundamental makroekonomi. Dalam pengukuran risiko sistematis menggunakan beta pasar ( $\beta$ ). Menurut Alghifari (2013) beta pasar merupakan beta dari suatu sekuritas yang relatif terhadap risiko sistematis. Beta pasar dapat mengukur respon dari masing-masing sekuritas terhadap pergerakan pasar.

Risiko sistematis memiliki potensi dalam mempengaruhi tingkat kinerja suatu perusahaan dan harga pasar saham karena risiko tersebut bersifat tidak dapat dikontrol. Menurut Alghifari (2013) risiko sistematis dapat mendeskripsikan perubahan tinggi atau rendahnya return saham individu terhadap return saham pasar melalui nilai beta. Nilai beta akan mencerminkan risiko yang akan ditanggung oleh investor ketika terjadi perubahan returm pasar.

Beta saham memiliki hubungan positif terhadap imbalan saham. Ketika nilai beta saham naik maka imbalan saham juga akan meningkat. Hubungan antara nilai return saham dengan harga saham berbanding terbalik. Jika harga suatu saham meningkat tandanya return dari saham tersebut rendah. Dapat disimpulkan bahwa ketika beta saham naik akan menyebabkan harga saham turun, return dari saham tersebut meningkat yang berarti risiko sistematis naik (Alghifari, 2013).

\section{Hubungan tanggung jawab sosial dengan risiko sistematis}

Djoutsa et al. (2020) menjelaskan bahwa risiko sistematis yang berhubungan dengan perusahaan dapat dipengaruhi oleh keputusan manajemen dalam operasi, pendanaan, dan investasi perusahaan tersebut. Beberapa diantara keputusan manajemen akan mempengaruhi risiko sistematis perusahaan. Perusahaan yang ingin menerapkan praktik sosial terhadap lingkungan tentu dipengaruhi oleh keputusan manajemen. Keputusan manajemen menjadi salah satu faktor penting dalam menerapkan praktik sosial terhadap lingkungan. Integrasi CSR dan risiko sistematis dilihat sebagai investasi jangka panjang di mana jauh lebih relevan dan penting daripada biaya jangka pendek yang terlibat dalam integrasi mereka (Eriandani \& Wijaya, 2021). Oleh karena itu, risiko sistematis menjadi ukuran yang tepat dalam hubungan antara keputusan manajemen dalam praktik sosial dan volatilitas keuntungan perusahaan dalam jangka panjang.

Risiko sistematis yang tinggi dapat dikarenakan adanya potensi tuntutan hukum karena kinerja lingkungan dan sosial yang kurang. Xue et al (2017) melakukan penelitian yang mempelajari pengaruh dimensi operasional dan manajerial terhadap tingkat risiko perusahaan. Hasil penelitiannya menunjukkan bahwa CSR berpengaruh terhadap tingkat risiko perusahaan secara keseluruhan.

Perusahaan yang mengungkapkan kinerja ekonomi, lingkungan, sosial, dan masyarakat dideskripsikan sebagai perusahaan yang memiliki hubungan yang baik dengan pemangku kepentingan (Nayenggita et al., 2019). Hubungan tersebut memungkinkan perusahaan dapat mengantisipasi kekhawatiran pemangku kepentingan sehingga perusahaan dapat melakukan pelestarian lingkungan yang diharapkan dapat mengurangi ketidakstabilan keuangan perusahaan. Tanggung jawab sosial tidak hanya dapat meningkatkan manajemen risiko namun juga memberikan perlindungan kekayaan. Kinerja lingkungan yang tinggi dapat memungkinkan mengurangi risiko perusahaan (Bukit et al., 2018; Muhammad et al., 2015).

Cai et al. (2016) menjelaskan bahwa kinerja lingkungan yang baik dapat membawakan berbagai manfaat kepada masyarakat dan perusahaan. Manfaat peningkatan kinerja lingkungan dapat berasal dari berbagai sumber seperti peningkatan kekayaan pemegang saham melalui perlindungan seperti asuransi, manajemen risiko yang lebih baik, daya tarik 
pasar kepada pelanggan dengan pendekatan strategis, dan transparansi yang lebih baik. Dapat disimpulkan bahwa tanggung jawab sosial dapat mengurangi risiko sistematis perusahaan.

Risiko sistematis perusahaan merupakan risiko yang dapat mempengaruhi harga saham di pasar modal. Pada umumnya berdasarkan penelitian sebelumnya, risiko sistematis dapat diukur melalui besarnya nilai beta (Alghifari, 2013; Annisa et al., 2014; Azizah, 2018; Parhusip et al., 2017). Nilai beta merupakan parameter yang digunakan untuk mengetahui tingkat risiko sistematis. Nilai beta dapat menunjukkan sensitivitas harga saham terhadap pergerakan pasar modal.

Perusahaan yang mengungkapkan tanggung jawab sosial cenderung memiliki keterbukaan informasi yang lebih transparan tentang aktivitas pengelolaan lingkungan, karyawan, dan hasil dari upaya tersebut. Penelitian yang dilakukan oleh Bouslah et al. (2018) berpendapat bahwa pengungkapan dan transparansi tersebut memungkinkan pengurangan asimetri informasi antara perusahaan dan investor sehingga dapat mengurangi tingkat risiko sistematis perusahaan. Oleh karena itu, dapat disimpulkan sementara bahwa tanggung jawab sosial memiliki hubungan signifikan negatif terhadap risiko sistematis.

\section{$\boldsymbol{H}_{1}$ : Adanya pengaruh negatif antara tanggung jawab sosial terhadap risiko sistematis.}

\section{Pengaruh fleksibilitas keuangan dan investasi penelitian dan pengembangan sebagai pemoderasi}

Guo et al. (2020) menjelaskan bahwa hubungan antara CSR terhadap risiko sistematis dapat dipengaruhi oleh beberapa faktor lain. Penelitian ini akan menambahkan variabel moderasi fleksibilitas keuangan dan R\&D investment.

\section{Fleksibilitas keuangan}

Fleksibilitas keuangan mencerminkan kemampuan perusahaan mendapatkan keuntungan terhadap peluang yang tidak terduga ( atau situasi ekonomi memburuk, perusahaan yang memiliki fleksibilitas keuangan tinggi dinilai mampu mencegah efek destruktif. Kemudian, ketika adanya peluang keuntungan perusahaan juga mampu berinvestasi menggunakan biaya rendah (Kurt \& Hulland, 2013).

Perusahaan yang fleksibel secara finansial dapat memasuki pasar modal dengan mudah (Takami, 2016). Hal tersebut dapat memberikan jaminan kepada para pemangku kepentingan. Selain itu, daya saing perusahaan akan meningkat yang dapat mendorong pendapatan perusahaan bertambah. Semakin fleksibel perusahaan maka semakin efektif kemampuan perusahaan dalam mengubah jumlah dan waktu arus kas. Zhang et al. (2020) mendeskripsikan bahwa fleksibilitas keuangan mengacu pada kemampuan perusahaan dalam memperoleh sumber daya keuangan pada waktu yang tepat.

Fleksibilitas keuangan tinggi dapat membantu perusahaan mempertahankan kapasitas hutang sehingga perusahaan dapat memilih investasi yang lebih baik (Guo et al., 2020). Arslan-ayaydin et al. (2014) menyimpulkan ketika krisis keuangan terjadi, perusahaan dengan fleksibilitas keuangan akan memiliki peluang lebih besar untuk berinvestasi. Di samping itu, adanya keuangan yang fleksibel dapat membantu perusahaan dalam

JAA pembangunan keberlanjutan. Kinerja tersebut dapat meningkatkan loyalitas investor dalam pilihan investasi sehingga dapat mengurangi risiko sistematis perusahaan.

4.2 $\boldsymbol{H}_{2}$ : Fleksibilitas keuangan melemahkean hubungan antara CSR pada risiko sistematis. 


\section{Investasi penelitian dan pengembangan}

Invovasi perusahaan merupakan suatu proses eksplorasi untuk menciptakan produk atau layanan baru serta meningkatkan tingkat keefisiensi operasional (Ozer \& Zhang, 2014). Kemampuan inovasi dapat mendorong perkembangan perusahaan dan menciptakan kesejahteraan kepada para pemangku kepentingan. Research and development (R\&D) dapat menciptakan diferensiasi produk sehingga dapat meningkatkan daya saing dan keunggulan kompetitif perusahaan (Guo et al., 2020).

Perusahaan yang menuangkan investasi R\&D dalam kegiatan CSR dapat membantu membangun nama baik perusahaan sehingga dapat menjadi pilihan investasi para investor (Padgett \& Moura-leite, 2014). Selain itu, adanya investasi R\&D yang mendalam mengenai kesejahteraan sosial dapat memberikan layanan baru kepada pelanggan. Investasi R\&D dapat mendorong inovasi pengembangan produk dan layanan yang berkaitan dengan CSR seperti memperbagus produk yang lebih kreatif dan kompleks. Penerapan investasi R\&D yang dapat meningkatkan CSR seperti melakukan inovasi produk maupun mengembangkan proses produksi yang lebih ramah lingkungan. Dengan kata lain, investasi $R \& D$ dapat meningkatkan loyalitas pelanggan terhadap CSR di mana akan mengurangi risiko sistematis perusahaan.

\section{$\boldsymbol{H}_{3:}$ Investasi penelitian dan pengembangan melemabkan hubungan antara CSR pada risiko sistematis METODE}

Penelitian ini membahas pengaruh dari CSR terhadap risiko sistematis dari perusahaan yang terdaftar pada BEI pada periode tahun 2016 hingga tahun 2020. Periode penelitian menggunakan tahun 2016-2020 dengan alasan merupakan data terbaru. Penelitian menggunakan data panel dengan periode 5 tahun terakhir $(t=5)$. Analisis menggunakan data panel dapat memudahkan peneliti menganalisa pasar saham dan melihat indikator kinerja ekonomi perusahaan yang terdaftar di BEI selama beberapa tahun terakhir. Pengambilan data menggunakan purposive sampling di mana sampel tersebut harus memenuhi kriteria tertentu. Tabel 1 menunjukkan seleksi data yang dapat dijadikan sebagai sampel. Kriteria-kriteria yang termasuk sampel yaitu: (1) Perusahaan yang terdaftar di BEI periode 2016-2020; (2) Perusahaan memiliki laporan tahunan lengkap yang terdaftar di BEI dari periode 2016 hingga 2020; (3) Perusahaan memiliki laporan keberlanjutan yang dibutuhkan untuk penelitian pada tahun 2016 - 2020; (4) Perusahaan memiliki harga saham pasar dari periode tahun 2016 hingga 2020 yang terdaftar di situs www.finance.yahoo.com.

\begin{tabular}{lcl}
\hline Keterangan & Jumlah & \\
\hline Perusahaan terdaftar di BEI per 27 Apr 2021 & 730 Perusahaan \\
Perusahaan yang tidak terdaftar di BEI 2016-2020 & $(217)$ Perusahaan \\
Perusahaan yang tidak memiliki laporan tahunan 2016-2020 & (356) Perusahaan \\
Perusahaan yang tidak memiliki laporan keberlanjutan 2016-2020 & $(102)$ Perusahaan \\
Perusahaan yang tidak memiliki harga saham pasar 2016-2020 & $(12)$ Perusahaan \\
Perusahaan yang memenuhi kriteria & 43 Perusahaan \\
Jumlah data penelitian (43 x 5) & 215 Data \\
\hline
\end{tabular}

Sumber: Data sekunder yang diolah, 2021

Tabel 2 merincikan hasil uji outlier untuk ketiga model penelitian. Uji outlier dilakukan untuk menghapus data-data yang menyimpang. Pengujian menggunakan metode Studentized Deleted Residual (SDR) (Winarno, 2009). Nilai residual dikatakan menyimpang jika lebih besar dari $+1,96$ dan lebih kecil dari -1,96. Maka jumlah data yang digunakan untuk menguji hipotesis 
untuk model 1 sebanyak 194 data, model 2 sebanyak 178 data, dan model 3 sebanyak 181 data.

\begin{tabular}{lccc}
\hline & $\begin{array}{c}\text { Model 1 } \\
\text { (CSR) }\end{array}$ & $\begin{array}{c}\text { Model 2 } \\
\text { (CSR*FLEX) }\end{array}$ & $\begin{array}{c}\text { Model 3 } \\
\text { (CSR*RD) }\end{array}$ \\
\hline Jumlah data sebelum outlier & 215 data & 215 data & 215 data \\
Jumlah data outlier & $(21)$ data & $(37)$ data & (34) data \\
Jumlah data penelitian & 194 data & 178 data & 181 data \\
\hline
\end{tabular}

Tabel 2.

Data penelitian model

Sumber: Data sekunder yang diolah, 2021

\section{Variabel dan definisi operasional variabel}

\section{Variabel dependen}

Risiko sistematis merupakan risiko pada pasar saham. Risiko ini dapat diukur dengan melalui koefisien beta $\beta$. Beta saham mencerminkan sensivitas saham dengan pergerakan pasar saham. Beta mengukur tingkat kepekaan pengembalian sekuritas yaitu dengan pengembalian pasar. Beta dihitung dengan regresi imbalan harga saham dengan imbalan harga pasar (Eriandani \& Wijava, 2021; Xue et al., 2017).

Jika beta semakin besar maka menunjukkan semakin besar sensitivitas pengembalian sekuritas tersebut terhadap perubahan pengembalian pasar. Jika $\beta>1$ artinya saham cenderung mengalami kenaikan dan penurunan lebih tinggi dibandingkan dengan perubahan pasar. Jika $\beta<1$ berarti saham cenderung mengalami penurunan atau kenaikan lebih rendah daripada perubahan pasar. Oleh karena itu, risiko sistematis yang tinggi akan mengurangi ketertarikan investor dalam melakukan investasi (Parhusip et al., 2017).

Pengambilan data beta saham dari harga saham perusahaan setiap periode dan indeks IHSG. Dengan menghitung return saham dan return saham IHSG ( $\underline{\text { A Muhammad \& }}$ Witiastuti, 2016). Rumus menghitung return saham sebagai berikut:

$R t=\frac{P_{t}-P_{t-1}}{P_{t-1}}$

$\mathrm{R}_{\mathrm{t}} \quad=$ return saham pasar pada tahun ke-t

$\mathrm{P}_{\mathrm{t}} \quad=$ harga saham pasar pada tahun ke- $\mathrm{t}$

$\mathrm{P}_{\mathrm{t}-1} \quad=$ harga saham pasar pada tahun ke $\mathrm{t}-1$

Rumus beta dapat dijabarkan sebagai berikut (Xue et al., 2017) :

$\beta=$ Correlation $(R p, R m) \frac{\delta p}{\delta m}$

$\beta=\frac{\text { Covariance }(R p, R m)}{\text { Variance }(R m)}$

Di mana:

JAA $\mathrm{Rm}=$ Pengembalian pasar

4.2 Rp = Pengembalian portofolio

$\delta p=$ Standar deviasi portofolio 
$\delta m=$ Standar deviasi pasar

Variabel independen

Tanggung jawab sosial perusahaan dapat dilihat dari pengungkapan pada laporan keberlanjutan perusahaan (Tahu, 2019). Pelaporan tanggung jawab sosial yang menilai kinerja ekonomi, lingkungan, sosial, dan masyarakat dengan menggunakan indeks GRI G4 atau Global Reporting Iniative (Juniawati, 2018). Penelitian ini akan menggunakan indeks GRI G4 yang terdiri dari 91 item dengan pengukuran binari.

\section{Variabel kontrol}

Ukuran perusahaan atau firm size (SIZE) merupakan salah satu variabel penentu terhadap tingkat risiko perusahaan. Ukuran perusahaan dapat dihitung melalui logaritma natural dari

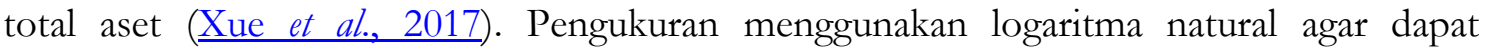
menyederhanakan data ukuran perusahaan yang besar hingga triliun tanpa mengubah proposi yang sebenarnya (Dang et al., 2017; Setiawan \& Mahardika, 2019).

Profitabilitas dapat diukur melalui return of asset (ROA) dan return of equity (ROE). Penelitian yang dilakukan menjelaskan bahwa ROA dan ROE dapat mempengaruhi profitabilitas saham dan tingkat risiko sistematis perusahaan (Campbell et al., 2010). Oleh karena itu, Cai et al. (2016) dan Djoutsa et al. (2020) menggunakan kedua rasio profitabilitas (ROA dan $\mathrm{ROE}$ ) untuk mengendalikan risiko sistematis. ROA merupakan rasio yang menunjukkan kemampuan perusahaan dalam menggunakan sumber daya alamnya (Nuzula et al., 2019). Suatu perusahaan yang memiliki ROA tinggi maka akan menghasilkan keuntungan perusahaan yang tinggi di mana semakin baik perusahaan mengelola aset yang ( Lautania, 2016). Rumus menghitung ROA sebagai berikut (utri et al., 2017):

\section{ROA $=\frac{\text { Laba setelah pajak }}{\text { Total Aset }}$}

ROE adalah rasio yang mengukur efektif perusahaan menggunakan modal atau equitas untuk menghasilkan keuntungan yang maksimal (Putri et al., 2017). Rasio ini menilai efisiensi dalam memanfaatkan modal yang ada. Jika ROE semakin tinggi berarti posisi pemiliki perusahaan semakin kuat. Rumus menghitung ROE sebagai berikut (Peranginangin, 2019):

\section{ROE $=\frac{\text { Laba setelah pajak }}{\text { Total Equitas }}$}

Dividen merupakan tanda tersedianya keuntungan perusahaan dan nilai pembayaran dividen memberikan informasi pertumbuhan tingkat keuntungan (Asmirantho \& Yuliawati, 2015). Dividend per share (DPS) diperlukan untuk mengetahui seberapa besar keuntungan yang diperoleh dari investasi pasar saham. DPS menunjukkan jumlah sebenarnya dari dividen dibagikan per lembar saham ( $\underline{\text { Arsal, 2021)}}$.

Dividend payout ratio (DPR) adalah rasio yang menghitung banyaknya keuntungan yang dibagikan untuk pemegang saham dengan keuntungan bersih yang dihasilkan perusahaan tersebut (Nana \& Erman, 2017). Rasio tersebut dapat dihitung dengan rumus di bawah ini:

$D P R=\frac{\text { Dividen yang dibayarkan }}{\text { Laba bersih perusahaan }}$ 


\section{3 \\ $D P R=\frac{D P S}{E P S}$}

Kualitas tata kelola (CGI) suatu perusahaan akan memiliki pengaruh terhadap investor, kinerja keuangan, dan tingkat risiko perusahaan (Djoutsa et al., 2020). Hapsari (2017) menjelaskan bahwa penerapan tata kelola perusahaan diharapkan dapat meningkatkan kemajuan terhadap kinerja perusahaan. Tata kelola yang baik dapat meningkatkan transparansi informasi kinerja perusahaan. Transparansi informasi akan dibutuhkan oleh pasar. Good corporate governance adalah suatu sistem yang dapat mengontrol dan mengatur perusahaan sehingga dapat menghasilkan nilai tambah untuk stakeholders (Salsabila \& Muhammad, 2017). Pengambilan data tata kelola perusahaan menggunakan indeks governance quality yang terdiri dari 7 item melalui pengukuran binari di mana jika sesuai dengan indeks dinilai 1 jika tidak 0 . Indeks tersebut meliputi komposisi direksi, aktivitas direksi, komite audit, dan kepemilikan saham (Lee et al., 2014). Penjabaran detail indeks tersebut disajikan pada lampiran 2.

\section{Variabel moderasi}

Penelitian ini menggunakan fleksibilitas keuangan dan investasi penelitian dan pengembangan sebagai variabel moderasi. Variabel fleksibilitas keuangan dapat diukur menggunakan rasio hutang terhadap aset. Penelitian ini menggunakan perhitungan yang direkomendasikan oleh Kurt dan Hulland (2013) yaitu dengan menghitung rasio hutang kemudian dikurangi rata-rata rasio hutang industri dibagi dengan standar deviasi rasio hutang dan dikalikan dengan minus 1 . Investasi penelitian dan pengembangan diukur menggunakan pengeluaran penelitian dan pengembangan dibagi dengan total penjualan (Honoré et al., 2015).

\section{Teknik dan model penelitian}

Pendekatan kuantitatif adalah metode tradisional yang sering dipakai oleh para peneliti. Data pendekatan kuantitatif sebagian besar akan dihitung dan dianalisis menggunakan matematika ataupun statistik (Space, 2014). Penelitian ini akan menggunakan pendekatan kuantitatif di mana data yang diambil berbentuk angka dari laporan tahunan perusahaan yang kemudian diolah menggunakan aplikasi Eviews 11. Informasi dari laporan tahunan perusahaan merupakan data sekunder yang diunduh dari website.

Penelitian ini akan menguji statistik deskriptif, pengujian outlier, pengujian model terbaik (uji Chow dan uji Hausman), dan pengujian hipotesis. Penelitian model 1 akan menguji pengaruh CSR terhadap risiko sistematis dan variabel kontrol lainnya. Model 2 akan menambahkan fleksibilitas keuangan sebagai variabel moderasi. Model terakhir menggunakan investasi R\&D sebagai variabel moderasi. Berikut merupakan persamaan regresi:

$$
\begin{aligned}
\text { BETA }_{i t}= & \alpha_{0}+\alpha_{1} \mathrm{CSR}_{\mathrm{it}}+\alpha_{2} \mathrm{SIZE}_{\mathrm{it}}+\alpha_{3} \mathrm{ROA}_{\mathrm{it}}+\alpha_{4} \mathrm{ROE}_{\mathrm{it}}+\alpha_{5} \mathrm{DPR}_{\mathrm{it}}+\alpha_{6} \mathrm{DPS}_{\mathrm{it}} \\
& +\alpha_{7} \mathrm{CGI}_{\mathrm{it}}+\varepsilon_{\mathrm{it}} \\
\mathrm{BETA}_{\mathrm{it}}= & \alpha_{0}+\alpha_{1} \mathrm{CSR}_{\mathrm{it}}+\alpha_{2} \mathrm{FLEX}_{\mathrm{it}}+\alpha_{3} \mathrm{CSR}_{\mathrm{it}}{ }^{*} \mathrm{FLEX}_{\mathrm{it}}+\alpha_{4} \mathrm{SIZE}_{\mathrm{it}}+\alpha_{5} \mathrm{ROA}_{\mathrm{it}}+ \\
& \alpha_{6} \mathrm{ROE}_{\mathrm{it}}+\alpha_{7} \mathrm{DPR}_{\mathrm{it}}+\alpha_{8} \mathrm{DPS}_{\mathrm{it}}+\alpha_{9} \mathrm{CGI}_{\mathrm{it}}+\varepsilon_{\mathrm{it}}
\end{aligned}
$$

$$
\begin{aligned}
\mathrm{BETA}_{\mathrm{it}}= & \alpha_{0}+\alpha_{1} \mathrm{CSR}_{\mathrm{it}}+\alpha_{2} \mathrm{RD}_{\mathrm{it}}+\alpha_{3} \mathrm{CSR}_{\mathrm{it}} * \mathrm{RD}_{\mathrm{it}}+\alpha_{4} \mathrm{SIZE}_{\mathrm{it}}+\alpha_{5} \mathrm{ROA}_{\mathrm{it}}+ \\
& \alpha_{6} \mathrm{ROE}_{\mathrm{it}}+\alpha_{7} \mathrm{DPR}_{\mathrm{it}}+\alpha_{8} \mathrm{DPS}_{\mathrm{it}}+\alpha_{9} \mathrm{CGI}_{\mathrm{it}}+\varepsilon_{\mathrm{it}}
\end{aligned}
$$


HASIL DAN PEMBAHASAN

\begin{tabular}{lcl}
\hline \multicolumn{1}{c}{ Model } & Prob & \multicolumn{1}{c}{ Kesimpulan } \\
\hline Model 1 (CSR) & 0,0000 & Fixed effect model (FEM) \\
Model 2 (CSR ${ }^{*}$ FLEX) & 0,0000 & Fixed effect model (FEM) \\
Model 3 (CSR ${ }^{*}$ RD) & 0,0000 & Fixed effect model (FEM) \\
\hline
\end{tabular}

Sumber: Data sekunder yang diolah, 2021

Sebelum ke tahap pengujian hipotesis, perlu melakukan pengujian model terbaik. Tahap pengujian menggunakan uji Chow dan uji Hausman. Pengujian tersebut bertujuan untuk memilih model terbaik dari fixed effect model (FEM), random effect model (REM), dan common effect model. Hasil pengujian Chow, jika probabilitas lebih kecil dari 0,05 maka model terbaik berupa FEM. Tabel 3 menunjukkan hasil uji Chow untuk ketiga model terbaik yaitu fixed effect model (prob $<0,05)$.

Tabel 4.

Hasil uji

\begin{tabular}{lcl}
\hline \multicolumn{1}{c}{ Model } & Prob & \multicolumn{1}{c}{ Kesimpulan } \\
\hline Model 1 (CSR) & 0,0019 & Fixed effect model (FEM) \\
Model 2 (CSR*FLEX) & 0,0021 & Fixed effect model (FEM) \\
Model 3 (CSR*RD) & 0,0000 & Fixed effect model (FEM) \\
\hline
\end{tabular}

Sumber: Data sekunder yang diolah, 2021

Selanjutnya uji Hausman bertujuan untuk menentukan model terbaik antara FEM dan REM. Jika probabilitas lebih kecil dari 0,05 maka model terbaik berupa FEM. Dari tabel 4 mendeskripsikan model terbaik untuk ketiga model yaitu fixed effect model (prob <0,05).

\begin{tabular}{lccccc}
\hline \multicolumn{1}{c}{ Variabel } & N & Rata-rata & Maks & Min & $\begin{array}{c}\text { Std } \\
\text { Deviasi }\end{array}$ \\
\hline BETA & 215 & 0,9944 & 2,3084 & $-0,1522$ & 0,5063 \\
CSR & 215 & 0,3059 & 0,7363 & 0,0330 & 0,1549 \\
FLEX & 215 & $-0,0000$ & 2,0976 & $-5,4669$ & 1,0000 \\
RD & 215 & 0,0085 & 0,2580 & 0,0000 & 0,0253 \\
ROA & 215 & 0,0457 & 0,5267 & $-0,1143$ & 0,0891 \\
ROE & 215 & 0,1201 & 1,4509 & $-2,5434$ & 0,3200 \\
DPR & 215 & 0,3566 & 6,1082 & $-8,8156$ & 1,0059 \\
DPS & 215 & 167,9239 & 3.465 & 0,0000 & 395,7815 \\
SIZE (dlm & 215 & 151.000 & 1.510 .000 & 2.110 & 301.000 \\
miliyar) & 215 & 0,4339 & 0,6452 & 0,2581 & 0,0899 \\
CGI & & & & & \\
\hline
\end{tabular}

Sumber: Data sekunder yang diolah, 2021

Beta saham merupakan tolak ukur variabel dependen dari penelitian yaitu risiko sistematis. Untuk menghitung beta saham didapatkan dari regresi harga saham perusahaan dengan harga pasar (Annisa et al., 2014). Menurut Ariyani, 2016 menjelaskan bahwa risiko sistematis memiliki hubungan dengan pergerakan harga pasar. Dapat dilihat dari Tabel 5 bahwa nilai rata-rata beta saham sebesar 0,9944. Maka dapat disimpulkan dari 215 data yang diolah menunjukkan nilai $\beta$ mendekati 1 yang artinya sebagian besar perusahaan memiliki harga saham cenderung mengalami fluktuatif lebih tinggi dibandingkan dengan perubahan pasar. 
Tanggung jawab sosial yang diukur menggunakan indeks GRI merupakan variabel independen yang mengukur kinerja perusahaan. Darmawati (2015) mendeskripsikan bahwa skor CSR menjelaskan upaya perusahaan dalam melestarikan lingkungan dalam operasional. Nilai skor CSR memiliki nilai rata-rata 0,3059 atau sebesar 30,59\% dari skala 100\%. Dari data yang diolah dapat disimpulkan pengungkapan atau pelaksanaan tanggung jawab sosial yang dilakukan oleh sebagian besar perusahaan menunjukkan rendah. Hal tersebut mencerminkan sebagian besar perusahaan perlu lebih memberi perhatian dalam upaya melestarikan lingkungan, hubungan karyawan, masyarakat, dan pelanggan.

\section{Pengujian hipotesis}

Uji F berfungsi untuk dapat menjelaskan pengaruh variabel secara bersama-sama terhadap variabel dependen. Dari Tabel 6 dapat dilihat nilai probabilitas untuk ketiga model sebesar 0,0000 atau lebih kecil dari 0,05. Maka dapat dijelaskan bahwa variabel dalam model 1, 2 dan 3 secara stimultan mempengaruhi risiko sistematis.

\begin{tabular}{lcc}
\hline Variabel Dependen (Beta) & Prob & Kesimpulan \\
\hline Model 1 (CSR) & 0,0000 & Signifikan \\
Model 2 (CSR FLEX) & 0,0000 & Signifikan \\
Model 3 (CSR*RD) & 0,0000 & Signifikan \\
\hline
\end{tabular}

Tabel 6.

Hasil pengujian uji statistik F

Sumber: Data sekunder yang diolah, 2021

Tabel 7 menunjukkan adjusted R-square pada model 1, 2, dan 3 sebesar 71,07\%, 69,86\%, dan $58,55 \%$. Nilai adjusted $\mathrm{R}$-squared semakin mendekati angka 1 artinya variabel independen, moderasi, dan kontrol semakin baik menjelaskan variasi dari variabel dependen. Dari nilai tersebut menjelaskan bahwa variabel CSR (model 1), dan penambahan variabel moderasi fleksibilitas keuangan (model 2) serta variabel kontrol lainnya cukup baik dapat menjelaskan variasi dari risiko sistematis. Namun untuk variabel CSR yang ditambah dengan investasi R\&D sebagai moderasi dan variabel kontrol hanya dapat menjelaskan 58,55\%. Kemudian sebanyak $41,45 \%$ lainnya dijelaskan oleh variabel-variabel yang tidak terdapat pada penelitian ini.

Berdasarkan tabel hasil pengujian (Model 1) di atas dapat dilihat bahwa nilai probabilitas CSR lebih kecil dari 0,05. Dalam penelitian ini menjelaskan bahwa CSR yang diukur menggunakan indeks GRI berpengaruh positif terhadap risiko sistematis perusahaan dan bertolak belakang dengan hipotesis yang telah dibahas sebelumnya. Penelitian ini memiliki hasil yang sama dengan penelitian Afifah dan Syafruddin (2021) yang juga menggunakan sampel perusahaan Indonesia namun belum sejauh ini belum ada teori yang dapat mendukung hasil ini. Hasil tersebut berbeda dengan hasil penelitian Cai et al. (2016), Muhammad et al. (2015), Bukit et al. (2018), dan Djoutsa et al. (2020) yang berhasil membuktikan bahwa CSR berpengaruh signifikan negatif terhadap risiko sistematis. Matsumura et al. (2014) menjelaskan bahwa tanggung jawab sosial yang baik memungkinkan perusahaan mengungkapkan informasi lebih transparan mengenai aktivitas lingkungan mereka. Pengungkapan dan transparansi tersebut dapat menurunkan terjadinya kesimetrian informasi antara para investor dengan perusahaan sehingga akan mengurangi tingkat risiko sistematis perusahaan. Menurut teori pemangku kepentingan, CSR dapat memenuhi harapan pemangku kepentingan yang berbeda bagi perusahaan (Guo et al., 2020). Investor dapat membeli atau menjual saham tidak hanya melihat dari kinerja 4.2 perusahaan sebagai return namun juga memperhatikan kinerja dalam tanggung jawab sosial.

Adapun hasil penelitian yang dilakukan Jung et al. (2018), Paragina dan Leon (2020), Park et al. (2017), Silalahi et al. (2020), dan Xue et al. (2017) yang menjelaskan bahwa hubungan 
tanggung jawab sosial tidak signifikan terhadap risiko sistematis. Vo dan Arato (2019) menekankan adanya perbedaan karakteristik CSR di negara berkembang dan negara maju. Hasil penelitian yang tidak signifikan dapat adanya kesulitan dalam menemukan keterlibatan lingkungan perusahaan di Indonesia. Dari data yang diuji dari sampel perusahaan di Indonesia masih banyak perusahaan yang tidak mengungkapkan laporan keberlanjutan. Pemerintah diharapkan dapat mendorong perusahaan untuk mengimplementasi CSR.

\begin{tabular}{lccc}
\hline & Model 1 & Model 2 & Model 3 \\
\hline CSR & 0,4775 & 0,4211 & 0,7174 \\
FLEX & $(0,0169)$ & $(0,0480)$ & $(0,0238)$ \\
CSR*FLEX & & 0,0049 & \\
RD & & $(0,9719)$ & \\
& & 0,1777 & \\
CSR*RD & $(0,3669)$ & 27,8856 \\
& & & $(0,0295)$ \\
ROA & & $-117,939$ \\
& & & $(0,0005)$ \\
ROE & & -3.1016 \\
SIZE & $-0,4978$ & $-3,3931$ & $(0,0847)$ \\
& $(0,6512)$ & $(0,0000)$ & $-0,2205$ \\
DPR & $-0,6698$ & 0,5138 & $(0,6914)$ \\
& $(0,0773)$ & $(0,0002)$ & 0,7564 \\
DPS & 0,5247 & 0,5119 & $(0,0000)$ \\
& $(0,0000)$ & $(0,0004)$ & 0,0473 \\
CGI & 0,0213 & 0,02905 & $(0,3806)$ \\
& $(0,4988)$ & $(0,3749)$ & $-0,0004$ \\
Adjusted R-Square & 0,0000 & 0,0001 & $(0,2468)$ \\
Jumlah data & $(0,2820)$ & $(0,1761)$ & $-0,3349$ \\
S & $-0,6526$ & $-0,7348$ & $(0,3981)$ \\
& $(0,0126)$ & $(0,0076)$ & 0,5355 \\
& 0,7107 & 0,6986 & 181 \\
\hline
\end{tabular}

Sumber: Data sekunder yang diolah, 2021

Variabel kontrol ROA, ROE, DPR, DPS (model 1) tidak berpengaruh signifikan pada risiko perusahaan. Variabel tersebut tidak pengaruh terhadap risiko karena investor dalam melakukan keputusan investasi cenderung menganalisis teknikal daripada fundamental. Analisis teknikal berarti investor melakukan analisis kondisi pasar dan faktor eksternal yang mempengaruhi saham perusahaan (Paragina \& Leon, 2020). Ukuran perusahaan memiliki signifikansi di bawah 0,05 yang menunjukkan hubungan signifikan positif terhadap risiko sistematis. Hasil penelitian selaras dengan penelitian yang dilakukan Hamidah dan Subhan (2015), Nana dan Erman (2017). Perusahaan yang semakin besar dan kompleks akan meningkatkan risiko. Jika terdapat perubahan lingkungan maka perusahaan besar akan lebih merasakan dampaknya. Tata kelola berpengaruh signifikan negatif terhadap risiko sistematis. Perusahaan yang memiliki tata kelola yang tinggi akan mengurangi risiko sistematis perusahaan. Penelitian ini sejalan dengan penelitian Cai et al. (2016) dan Djoutsa et al. (2020).

Variabel moderasi fleksibilitas keuangan (model 2) tidak mempengaruhi hubungan antara CSR dan risiko sistematis $(p>0,05)$. Hasil ini bertolak belakang dengan hipotesis dan 
penelitian yang dilakukan dengan Guo et al. (2020) yang menjelaskan bahwa fleksibilitas keuangan dapat memperlemah hubungan CSR dan risiko. Perusahaan yang fleksibel keuangannya dapat meningkatkan dampak menguntungkan dari CSR pada risiko sistematis (Guo et al., 2020).

Tabel 7 menunjukkan investasi R\&D (model 3) dapat mempengaruhi hubungan CSR pada risiko sistematis $(\mathrm{p}<0,05)$. Investasi $R \& D$ dapat memperlemah hubungan CSR pada risiko sistematis sehingga hipotesis diterima (Guo et al., 2020). Inovasi dalam CSR diharapkan dapat meningkatkan daya saing dan keunggulan kompetitif perusahaan. Secara umum pengembangan inovasi dapat mendorong perusahaan mendapatkan keuntungan yang berkelanjutan yang dapat mengurangi risiko sistematis. Teori kontinjensi menjelaskan untuk mencapai efektivitas setiap perusahaan memiliki struktur yang berbeda-beda sesuai dengan kondisinya. Berdasarkan hasil penelitian menunjukkan bahwa variabel investasi dan pengembangan dengan sampel perusahaan di Indonesia dapat mempengaruhi hubungan CSR dan risiko sistematis.

Pengungkapan CSR di Indonesia yang merupakan negara berkembang masih sangat sedikit dan relatif dasar. Jika praktik CSR perusahaan masih sedikit maka akan sulit untuk mengimplikasikan pada kinerja keuangan. Pemahaman investor di negara berkembang masih relatif lemah dibandingkan investor negara maju. Oleh karena itu, sebagian besar modus investasi tidak dapat dikaitkan secara langsung dengan tanggung jawab sosial.

\section{SIMPULAN}

Penelitian digunakan untuk melakukan pengujian pengaruh tanggung jawab sosial perusahaan terhadap risiko sistematis dari perusahaan yang terdaftar di Bursa Efek Indonesia (2016-2020). Variabel dependen yang digunakan merupakan tanggung jawab sosial yang diukur dari skor CSR dengan standar GRI G4. Adapun variabel kontrol terdiri dari ROA, ROE, ukuran perusahaan, DPS, DPR, dan tata kelola perusahaan. Selain itu, penelitian ini juga menambahkan fleksibilitas keuangan dan investasi $R \& D$ sebagai pemoderasi. Dari hasil penelitian menjelaskan bahwa variabel CSR berpengaruh signifikan positif terhadap risiko sistematis perusahaan. Hasil tersebut berbeda dengan hipotesis yang dibuat dan sejauh ini belum ada teori yang dapat mendukung. Berdasarkan penelitian terdahulu, tanggung jawab sosial perusahaan yang baik dapat mengurangi risiko sistematis. Hasil penelitian dengan menambahkan variabel moderasi fleksibilitas keuangan tidak berpengaruh terhadap hubungan CSR dan risiko sistematis. Akan tetapi penambahan variabel investasi $\mathrm{R} \& \mathrm{D}$ sebagai pemoderasi memperlemah hubungan CSR dan risiko sistematis.

Temuan penelitian ini memiliki implikasi teori yaitu memperluas teori pemangku kepentingan dan teori kontinjensi. Penelitian ini menunjukkan bahwa investasi R\&D dapat memperlemah hubungan CSR pada risiko sistematis. Kesimpulan tersebut mendukung dan memperkaya teori kontinjensi. Untuk memanfaatkan aset pasar dengan sepenuhnya, faktor kapasitas internal seperti investasi $R \& D$ juga perlu dipertimbangkan. Penelitian ini memperdalam pengetahuan tentang interaksi investasi R\&D terhadap hubungan CSR yang dapat mengurangi risiko sistematis. Perusahaan dalam membangun inovasi dan keberlanjutan, investasi R\&D menjadi salah satu peran penting. Dengan penelitian ini, diharapkan manajer dalam membuat kebijakan CSR perlu mempertimbangkan pasar dan

4.2 pesaing. Penelitian ini menyoroti masalah pengungkapan praktik CSR di Indonesia yang masih sedikit. Adapun keterbatasan penelitian seperti belum terdapat teori yang dapat mendukung hasil penelitian hubungan positif antara CSR dengan risiko sistematis. Oleh karena itu, penelitian ini dapat menjadi langkah pertama untuk serangkaian studi mengkaji 
lebih dalam hubungan positif antara CSR dan risiko sistematis di negara Indonesia. Selain itu, masih sedikit pengungkapan CSR perusahaan pada laporan keberlanjutan di Indonesia. Adapun harapan untuk penelitian selanjutnya (1) menemukan teori yang mendukung hubungan CSR dan risiko sistematis; (2) memperbanyak sampel perusahaan.

\section{LAMPIRAN}

Lampiran 1 Pengukuran variable

\begin{tabular}{|c|c|c|}
\hline Variabel & Pengukuran & Sumber \\
\hline \multirow[t]{2}{*}{ BETA } & $\begin{array}{l}\text { Risiko sistematis. Meregresikan imbalan harga saham } \\
\text { perusahaan dengan imbalan pasar IHSG. } \\
\text { Covariance }(R p, R m)\end{array}$ & $\begin{array}{l}\text { www.finance.yaho } \\
\text { o.com }\end{array}$ \\
\hline & Variance $(R m)$ & \\
\hline CSR & $\begin{array}{l}\text { Tanggung jawab sosial. Total indeks yang memenuhi } \\
\text { GRI G4 / } 91\end{array}$ & $\begin{array}{l}\text { Laporan } \\
\text { keberlanjutan }\end{array}$ \\
\hline FLEX & $\begin{array}{l}\text { Fleksibilitas keuangan. Menghitung rasio hutang } \\
\text { dengan total hutang dibagi dengan total aset. } \\
\text { Kemudian rasio hutang industri dikurangi rasio } \\
\text { hutang perusahaan, dibagi dengan standar deviasi } \\
\text { rasio hutang, dan dikali -1. }\end{array}$ & Laporan tahunan \\
\hline $\mathrm{RD}$ & $\begin{array}{l}\text { Investasi R\&D. Pengeluaran R\&D dibagi total } \\
\text { penjualan }\end{array}$ & Laporan tahunan \\
\hline $\mathrm{ROA}$ & Return on asset. Laba setelah pajak dibagi total aset. & Laporan tahunan \\
\hline $\mathrm{ROE}$ & Return on equity. Laba setelah pajak dibagi total ekuitas. & Laporan tahunan \\
\hline $\mathrm{SIZE}$ & Ukuran perusahaan. Logaritma dari total aset. & Laporan tahunan \\
\hline DPS & $\begin{array}{l}\text { Dividen per saham. Total dividen yang dibayarkan } \\
\text { bagi lembar saham. }\end{array}$ & Laporan tahunan \\
\hline DPR & $\begin{array}{l}\text { Dividend payout ratio. Total dividen yang dibayarkan } \\
\text { bagi laba bersih. }\end{array}$ & Laporan tahunan \\
\hline CGI & $\begin{array}{l}\text { Tata kelola perusahaan. Indeks tata kelola yang } \\
\text { disaijikan di lampiran } 2 \text { dibagi } 7 \text {. Total item yang } \\
\text { memenuhi dibagi } 7 \text {. }\end{array}$ & Laporan tahunan \\
\hline
\end{tabular}

Lampiran 2 Indeks tata kelola

\begin{tabular}{|c|c|c|}
\hline Tipe & Komponen & Pengukuran \\
\hline \multirow{3}{*}{ Direksi } & Jumlah dewan direksi & $\begin{array}{l}\text { "1" jika jumlah direktur lebih besar dari } \\
\text { rata-rata sampel. "0" jika tidak. }\end{array}$ \\
\hline & Jumlah direktur & "1" jika jumlah direktur independen \\
\hline & independen & $\begin{array}{l}\text { lebih besar dari rata-rata sampel. " } 0 \text { " } \\
\text { jika tidak. }\end{array}$ \\
\hline \multirow{2}{*}{ Komite audit } & Komite audit & $\begin{array}{l}\text { " } 1 \text { " jika perusahaan terdapat komite } \\
\text { audit. " } 0 \text { " jika tidak terdapat komite } \\
\text { audit. }\end{array}$ \\
\hline & Independensi & $\begin{array}{l}\text { "1" jika semua anggota komite audit } \\
\text { independen. " } 0 \text { " jika tidak. }\end{array}$ \\
\hline \multirow{2}{*}{$\begin{array}{l}\text { Kepemilikan } \\
\text { saham }\end{array}$} & $\begin{array}{l}\text { Kepemilikan saham } \\
\text { terbesar }\end{array}$ & $\begin{array}{l}\text { "1" jika kepemilikan saham terbesar } \\
\text { lebih besar dari rata-rata sampel. "0" } \\
\text { jika tidak. }\end{array}$ \\
\hline & $\begin{array}{l}\text { Kepemilikan saham } \\
\text { asing }\end{array}$ & $\begin{array}{l}\text { "1" jika kepemilikan saham asing lebih } \\
\text { besar dari rata-rata sampel. " } 0 \text { " jika } \\
\text { tidak. }\end{array}$ \\
\hline
\end{tabular}


Auditor eksternal Auditor Big 4" jika auditor eksternal merupakan Big Four. "0" jika tidak.

\section{DAFTAR PUSTAKA}

A Muhammad, J., \& Witiastuti, R. S. (2016). Determinan beta saham perusahaan real estate dan property di BEI. Management Analysis Journal, 5(1), 63-69. https://doi.org/https://doi.org/10.15294/maj.v5i1.5779

Afifah, H. N., \& Syafruddin, M. (2021). Pengaruh corporate social responsibility terhadap kinerja keuangan perusahaan dengan risiko sebagai variabel mediasi. Diponegoro Journal of Accounting, 10(2), 1-14.

Agustin, Darminto, \& Handayani. (2013). Analisis rasio untuk menilai kinerja keuangan perusahaan. Jurnal Administrasi Bisnis (JAB), 2(1), 1-8.

Albuquerque, R., Koskinen, Y., \& Zhang, C. (2017). Corporate social responsibility and firm risk: theory and empirical evidence. Finance Working Paper. https://doi.org/http://doi.org/10.1287/mnsc.2018.3043

Alghifari, E. S. (2013). Pengaruh risiko sistematis terhadap kinerja perusahaan dan implikasinya pada nilai perusahaan (studi pada perusahaan food and beverage di Bursa Efek Indonesia tahun 2007-2011). Jurnal Ilmu Manajemen \& Bisnis, 04(01), 1-16. https://doi.org/https://doi.org/10.17509/jimb.v5i1.1009

Andriani, Y. (2010). Penerapan model indeks tunggal dalam menghitung beta saham Jakarta Islamic Index untuk mengukur risiko sistematis. Jurnal Penelitian Sains, 13(2(A)), 10-16. https://doi.org/https://doi.org/10.26554/jps.v13i2.145

Annisa, A., Didik, T., \& Azib. (2014). Pengaruh risiko sistematis terhadap return saham. Prosiding Manajemen, 1(2), 335-340. https://doi.org/http://dx.doi.org/10.29313/.v0i0.2028

Ariyani, T. T. (2016). Hubungan kinerja perusahaan, risiko sistematis, dan corporate social responsibility dengan return saham. Universitas Sanata Dharma Yogyakarta, 1(1).

Arsal, M. (2021). Impact of earnings per share and dividend per share on firm value. Journal Ilmiah Akuntansi, 4(1), 11-18. https://doi.org/https://doi.org/10.33096/atestasi.v4i1.594

Arslan-ayaydin, Ö., Florackis, C., \& Ozkan, A. (2014). Financial flexibility , corporate investment and performance: evidence from financial crises. Rev. Quant. Financ. Account, 42(2), 1-43. https://doi.org/10.1007/s11156-012-0340-x

Asmirantho, E., \& Yuliawati, E. (2015). Pengaruh dividen per share (DPS), dividen payout ratio (DPR), price to book value (PBV), debt to equity ratio (DER), net profit margin (NPM) dan return on asset (ROA) terhadap harga saham pada perusahaan manufaktur sub sektor makanan dan minuman dalam kem. JLAFE (Jurnal Ilmiah Akuntansi Fakultas Ekonomi), 1(2), 95-117. https://doi.org/10.34204/jiafe.v1i2.525

Azizah, D. F. (2018). Pengaruh risiko sistematis terhadap dan risiko tidak sistematis terhadap expected return portofolio optimal (studi pada perusahaan yang terdaftar di Jakarta Islamic Index tahun 2013-2017). Jurnal Administrasi Bisnis (JAB), 61(4).

Basu, S., \& Rizzuto, R. (1995). Fall 1995 Pitfalls in using the S \& P Bogey for financial analysis and portfolio management. Journal of Financial and Strategic Decisions, 8(3), 7795. 
Bouslah, K., Kryzanowski, L., \& M'Zali, B. (2018). Social performance and firm risk: impact of the financial crisis. Journal of Business Ethics, 149(3), 643-669. https://doi.org/10.1007/s10551-016-3017-x

Bukit, R. B., Haryanto, B., \& Ginting, P. (2018). Environmental performance, profitability, asset utilization, debt monitoring and firm value. IOP Conference Series: Earth and Environmental Science, 122(1). https://doi.org/10.1088/1755-1315/122/1/012137

Cai, L., Cui, J., \& Jo, H. (2016). Corporate environmental responsibility and firm risk. Journal of Business Ethics, 139(3), 563-594. https://doi.org/10.1007/s10551-015-2630-4

Campbell, Polk, J. Y. C., \& Vuoltenaaho Tuomo. (2010). Growth or glamour? fundamentals and systematic risk in stock returns. Review of Financial Studies, 23(1), 305-344. https://doi.org/10.1093/rfs/hhp029

Chabachib, M. (2020). In search of stock market proxy to calculate systematic risk (Beta) of stocks in Indonesia stock exchange. Jurnal Bisnis Strategi, 29(2), 81-88. https://doi.org/https://doi.org/10.14710/jbs.29.2.80-88

Dang, C., Li, Z. F., \& Yang, C. (2017). Measuring firm size in empirical corporate finance. SSRN Electronic Journal. https://doi.org/10.2139/ssrn.2345506

Darmawati, D. (2015). Pengaruh tanggung jawab sosial perusahaan terhadap kinerja dan risiko perbankan di Indonesia. Finance Banking and Journal, 17(1).

Darmayanti, N., Mildawati, T., \& Dwi Susilowati, F. (2021). Dampak Covid-19 terhadap perubahan harga dan return saham. EKUITAS Jurnal Ekonomi Dan Kenangan), 4(4), 462-480. https://doi.org/10.24034/j25485024.y2020.v4.i4.4624

Darwanis, D. S., \& Andina, A. (2013). Pengaruh risiko sistematis terhadap pengungkapan corporate social responsibility serta dampaknya terhadap pertumbuhan laba dan koefisien respon laba (studi pada perusahaan manufaktur yang terdaftar di Bursa Efek Indonesia). Jurnal Telaah Dan Riset Akuntansi, 6(1), 64-92.

Devie, D., Liman, L. P., Tarigan, J., \& Jie, F. (2019). Corporate social responsibility, financial performance and risk in Indonesian natural resources industry. Social Responsibility Journal. https://doi.org/10.1108/SRJ-06-2018-0155

Djoutsa, W. L., Sahut, J. M., Braune, E., \& Teulon, F. (2020). Does the optimization of a company's environmental performance reduce its systematic risk? New evidence from European listed companies. Corporate Social Responsibility and Environmental Management, 27(4), 1677-1694. https://doi.org/10.1002/csr.1916

Donaldson, T., \& Preston, L. (1995). The stakeholder theory of the corporation: concepts, Evidence, and implications. Academy of Management Review, 20(1), 65-91. https://doi.org/10.5465/amr.1995.9503271992

Eduarnus, T. (2001). Beta pada pasar Bullish dan Bearish: Studi empiris pada bursa efek Jakarta. Jurnal Ekonomi Dan Bisnis Indonesia, 16(3), 261-272.

Eriandani, R., \& Wijaya, L. I. (2021). Corporate social responsibility and firm risk: controversial versus noncontroversial industries. Economics and Business, 8(3), 953-965. https://doi.org/10.13106/jafeb.2021.vol8.no3.0953

Freeman, E. R. (1994). The politics of stakeholders theory: some future directions. Business Ethics Quarterly, 4(4), 409-421. https://doi.org/https://doi.org/10.2307/3857340

Globalnews.net. (2018). Kegiatan tambang PT BA sebabkan air Sungai Kiahan Keruh. 28 
Februari 2018, 1. http://globalplanet.news/berita/5081/kegiatan-tambang-pt-basebabkan-air-sungai-kiahan-keruh

Guo, Z., Hou, S., \& Li, Q. (2020). Corporate social responsibility and firm value: the moderating effects of financial flexibility and R\&D investment. Sustainability 2020, 12(20), 8452. https://doi.org/https://doi.org/10.3390/su12208452

Hamidah, \& Subhan, F. (2015). DER, DOL, EPS, ukuran perusahaan dan risiko sistematis saham perusahaan pertambangan di Bursa Efek Indonesia 2009-2012. Jurnal Bisnis Dan Komunikasi, 2(1), 11-19.

Hapsari, A. A. (2017). Pengaruh tata kelola perusahaan terhadap manajemen risiko pada perbankan Indonesia. Jurnal Muara Ilmu Ekonomi Dan Bisnis, 1(2), 1. https://doi.org/10.24912/jmieb.v1i2.936

Hassouna, D., \& Salem, R. (2021). Corporate social responsibility and firm risk: Egypt's case. Journal of Governance and Regulation, 10(2), 74-83. https://doi.org/10.22495/jgrv10i2art7

Hidayat, R., Yahya, A., Adli, M., \& Ernis, Y. (2020). Analisis yuridis tanggung jawab sosial dan lingkungan perusahaan terhadap masyarakat sekitar. Jurnal Penelitian Hukum De Jure, 20(10), 531-544. https://doi.org/http://dx.doi.org/10.30641/dejure.2020.V20.531-544

Honoré, F., Munari, F., \& Potterie, B. V. P. (2015). Corporate governance practices and companies R\&D intensity: evidence from European countries. Research Policy, 44(2), 533-543. https://doi.org/10.1016/j.respol.2014.10.016

Hsiao, C., Lin, X., Cen, K., \& Zheng, W. (2021). Relationship between corporate social responsibility performance and systematic risk — a case study of a-share listed Chinese Companies. Asian Journal of Economics, Business, and Accounting, 21(9), 66-76. https://doi.org/10.9734/AJEBA/2021/v21i930423

IDX. (2021). Idx statistics 2021. 6.

Jung, S., Kim, J. H., Kang, K. H., \& Kim, B. (2018). Internationalization and corporate social responsibility in the restaurant industry: risk perspective. Journal of Sustainable Tourism, 1-19. https://doi.org/10.1080/09669582.2017.1421201

Juniawati, M. (2018). Pengukuran pengungkapan tanggung jawab sosial perusahaan bank syariah di Indonesia. Jurnal Akuntansi Dan Perbankan Syariah, 01(02), 153-178.

Katz, D., \& Kahn, R. L. (1966). Ths social psychology of organizations. Wiley.

Kiryanto, Rohmatika, A., \& Amilahaq, F. (2021). Is corporate social responsibility able to mediate increased tax avoidance? Jurnal Reviu Akuntansi Dan Keuangan, 11(2), 346-365. https://doi.org/10.22219/jrak.v11i2.16470

KPMG. (2017). The road ahead: KPMG international survey of corporate responsibility reporting 2017. KPMG.

Kurt, D., \& Hulland, J. (2013). Aggresive marketing strategy following equity offerings and

JAA firm value: the role of relative strategic flexibility. Journal of Marketing, 77(September), 57-74. https://doi.org/https://doi.org/10.1509/jm.12.0078

4.2 Lee, M., Kang, M., Lee, H., \& Park, J. C. (2014). Related-party transactions and financial statement comparability: evidence from South Korea. Asia-Pacific Journal of Accounting \& Economics, 1-29. https://doi.org/10.1080/16081625.2014.957706 
Lestari, D. P. R., \& Candraningrat, I. R. (2013). Studi komparatif portofolio optimal menggunakan pendekatan model indeks tunggal. Jurnal Manajemen Bisnis Universitas Udayana, 12(1),

$578-594$. http://ojs.unud.ac.id/index.php/Manajemen/article/view/6911

Matsumura, E. M., Prakash, R., \& Vera-Muñoz, S. C. (2014). Firm-value effects of carbon emissions and carbon disclosures. The Accounting Review, 89(2), 695-724. https://doi.org/10.2308/accr-50629

Muhammad, N., Scrimgeour, F., Reddy, K., \& Abidin, S. (2015). The impact of corporate environmental performance on market risk: The Australian industry case. Journal of Business Ethics, 132(2), 347-362. https://doi.org/10.1007/s10551-014-2324-3

Nana, V. J., \& Erman, D. A. (2017). Pengaruh likuiditas, leverage, efisiensi operasi, dividend payout ratio, profitabilitas dan ukuran perusahaan terhadap risiko sistematis dan non sistematis. Diponegoro Journal of Management, 6(3), 1-14.

Nayenggita, G. B., Raharjo, S. T., \& Resnawaty, R. (2019). Praktik Corporate Social Responsibility (CSR) di Indonesia. Focus Jurnal Pekerjaan Sosial, 2(1), 61. https://doi.org/10.24198/focus.v2i1.23119

Nguyen, T. C., Vu, T. N., Vo, D. H., \& McAleer, M. (2020). Systematic risk at the industry level: A case study of Australia. Risks, 8(2), 1-12. https://doi.org/10.3390/risks8020036

Nuzula, N. F., Damayanti, C. R., \& Sulasmiyati, S. (2019). Pengaruh environmental risk terhadap kinerja keuangan perusahaan. Jurnal Profit, 13(2), 12-22. https://doi.org/https://doi.org/10.21776/ub.profit.2019.013.02.2

Ozer, M., \& Zhang, W. (2014). The effects of geographic and network ties on exploitative and exploratory product innovation. Strategic Management Journal, 26(7). https://doi.org/10.1002/smj

Padgett, R. C., \& Moura-leite, R. C. (2014). The impact of R\&D intensity on corporate reputation: interaction effect of innovation with high social benefit. Intangible Capital, 8(2), 216-238. https://doi.org/http://dx.doi.org/10.3926/ic.336

Paragina, A. B., \& Leon, F. M. (2020). Pengaruh CSR dan corporate governance terhadap risiko harga saham pada perbankan di Indonesia. ResearchGate, May.

Paramitasari, R. (2014). Pengaruh risiko sistematis dan risiko tidak sistematis terhadap expected return saham dalam rangka pembentukan portofolio saham LQ-45 yang terdaftar di Bursa Efek Indonesia dengan single index model periode tahun 2009. Jurnal Organisasi Dan Manajemen, 10(1), 78-83. https://doi.org/https://doi.org/10.33830/jom.v10i1.167.2014

Parhusip, P. T., Si, M., Silalahi, E., \& Si, M. (2017). Pengaruh faktor fundamental dan risiko sistematik terhadap return saham pada perusahaan manufaktur yang go publik di Bursa Efek Indonesia. Poltak \& Esl, 3(1), 71-88.

Park, S., Song, S., \& Lee, S. (2017). Corporate social responsibility and systematic risk of restaurant firms: The moderating role of geographical diversification. Tourism Management, 59, 610-620. https://doi.org/10.1016/j.tourman.2016.09.016

Peranginangin, A. M. (2019). The effect of profitabilty, debt policy and firm size on company value in consumer goods companies. Abstract Proceedings International Scholars 
Conference, 7(1), 1217-1229. https://doi.org/10.35974/isc.v7i1.1587

Prabowo, H. (2021). Halmahera dalam cengkeraman taipan tambang nikel \& pejabat korup. 12 Juli 2021, 1. https://tirto.id/halmahera-dalam-cengkeraman-taipan-tambang-nikelpejabat-korup-ghDB

Puspitaningtyas, Z. (2017). Estimating systematic risk for the best investment decisions on manufacturing company in Indonesia. Investment Management and Financial Innovations, 14(1), 46-54. https://doi.org/10.21511/imfi.14(1).2017.05

Putri, C. L., \& Lautania, M. F. (2016). Pengaruh capital intensity ratio, inventory intensity ratio, ownership structure dan profitability terhadap Effective Tax Rate (ETR) (studi pada perusahaan manufaktur yang terdaftar di Bursa Efek Indonesia tahun 2011-2014. Jurnal Ilmiah Mahasiswa Ekonomi Akuntansi JIMEKA), 1(1), 1. https://media.neliti.com/media/publications/188375-ID-pengaruh-capital-intensityratio-invento.pdf

Putri, L., Bakri, S. A., \& Bakar, S. W. (2017). Analisis DOL , DFL dan DCL terhadap profitablitas perusahaan. Jurnal Manajemen Dan Bisnis Sriwijaya, 15(2). https://doi.org/https://doi.org/10.29259/jmbs.v15i2.5697

Rahmani, D. A., Nugraha, \& IkaPutra, W. (2017). Pengaruh faktor-faktor fundamental saham dan risiko sistematis terhadap harga saham. Jurnal Ilmu Manajemen \& Bisnis, 8(1), 17-21. https://doi.org/https://doi.org/10.17509/jimb.v8i1.12657

Rahmawati. (2015). Determinan risiko sistematis dan kinerja saham pada sektor industri barafile konsumsi Bursa Efek Indonesia. Jumal MIX, V(3), 1-27. https://doi.org/10.22441/jurnal_mix

Raka. (2018). Perkembangan CSR di Indonesia. Amerta.Id. https://www.amerta.id/2018/04/25/1304/perkembangan-csr-di-indonesia.php

Rizwan, M. S., Ahmad, G., \& Ashraf, D. (2020). Systemic risk: The impact of Covid-19. Finance Research Letters, 36, 101682. https://doi.org/10.1016/j.frl.2020.101682

Rohmawati, E., \& Shenurti, E. (2020). The Influence of financial performance and corporate social responsibility on firm's value (for companies (food and beverage sector) listed in Bursa Efek Indonesia). Advances in Economics, Business and Management Research, 127(Aicar 2019), 82-85. https://doi.org/10.2991/aebmr.k.200309.019

Rorong, A., Saerang, I. S., \& Untu, V. (2017). Analisis risiko sistematis dan faktor fundamental terhadap harga saham pada perusahaan sektor properti yang terdaftar di Bursa Efek indonesia. Jurnal EMBA, Vol 5(No 3), ISSN 2303-1174. https://ejournal.unsrat.ac.id/index.php/emba/article/viewFile/18285/18197

Rosikah, Prananingrum, D. K., Muthalib, D. A., Muh, I. A., \& Miswar, R. (2018). Effects of Return on Asset, Return On Equity, Earning Per Share on corporate value. The International Journal of Engineering and Science (IJES, 7(3), 6-14. https://doi.org/10.9790/1813-0703010614

Salsabila, S., \& Muhammad, S. (2017). Pengaruh good corporate governance terhadap kinerja keuangan dan efeknya terhadap nilai perusahaan (studi pada badan usaha milik negara yang terdaftar di Bursa Efek Indonesia periode 2012-2015. Jurnal Administrasi Bisnis $S 1$ Universitas Brawijaya, 50(2), 146-153.

Santoso, R., \& Erstiawan, M. S. (2021). Implementation of financial risk management in 
Batik MSMEs during the Covid-19 pandemic. TEKMULOGI: Jurnal Pengabdian Masyarakat, 1(1), 1-7.

Sartono, R. A., \& Zulaihati, S. (1998). Rasionalitas investor terhadap pemilihan saham dan penentuan portofolio optimal dengan model indeks tunggal di BEJ. In Kelola: Vol. VII (Issue 17, pp. 107-121).

Schlevogt, K. (2002). Supranational visionary and builder of Euroland: former German chancellor Dr. Helmut Kohl on the Euro's significance for Germany and its neighbors. The Academy of Management Excecutive, 16(1), 8-12. https://doi.org/https://www.jstor.org/stable/4165805

Setiawan, I. G. N. A. P., \& Mahardika, D. P. K. (2019). Market to book value, firm size dan profitabilitas terhadap pengambilan keputusan lindung nilai (studi kasus pada perusahaan sub sektor otomotif dan komponennya yang terdaftar di Bursa Efek Indonesia pada tahun 2014-2017. Jurnal Ilmiah Akuntansi, 4(1), 124-140.

Silalahi, A. S., Dalimunthe, D. M. J., Sianipar, A. S., \& Saputra, J. (2020). The impact of corporate social responsibility practices through supply chain management on company risk in Indonesia. International Journal of Supply Chain Management, 9(5), 10821091.

Space, W. L. (2014). Research methods for business. Encyclopedia of Quality of Life and WellBeing Research, 3336-3336. https://doi.org/10.1007/978-94-007-0753-5_102084

Tahu, G. P. (2019). Pengaruh kinerja lingkungan dan pengungkapan lingkungan terhadap kinerja keuangan (studi pada perusahaan manufaktur yang terdaftar di BEI). Jurnal Akuntansi, Audit, Dan Sistem Informasi Akuntansi, 3(1), 14-26.

Takami, S. (2016). Flexibility in the global financial crisis period: the Japanese example. Corporate Accounting \& Finance, 27(4), 13-25. https://doi.org/10.1002/jcaf

Taliawo, N., \& Atahau, A. D. R. (2007). Beta dan implikasinya terhadap hasil diversifikasi saham di Bursa Efek Jakarta. Jurnal Bisnis Dan Ekonomi, 14(2007), 161-171.

Tambunan, D. (2020). Investasi saham di masa pandemi Covid-19. Widya Cipta: Jurnal Sekretari Dan Manajemen, 4(2), 117-123. https://doi.org/10.31294/widyacipta.v4i2.8564

Tunggal, W. S. P. (2014). Pengaruh environmental performance, environmental cost dan CSR disclosure terhadap financial performance. Accounting Analysis Journal, 3(3), 310320. https://doi.org/10.15294/aaj.v3i3.4200

Utami, M. R., \& Darmawan, A. (2019). Effect of DER, ROA, ROE, EPS and MVA on stock prices in Sharia Indonesian Stock Index. Journal of Applied Accounting and Taxation, 4(1), 15-22. https://doi.org/10.30871/jaat.v4i1.1195

Vo, H. T. M., \& Arato, M. (2019). Agroecology and sustainable food systems corporate social responsibility in a developing country context: a multi-dimensional analysis of modern food retail sector in Vietnam. Agroecology and Sustainable Food Systems, 0(00), 126. https://doi.org/10.1080/21683565.2019.1607797

Wibowo, I. G. B. E., \& Wibowo, B. (2017). The effect of competition level and banking concentration to systemic risks: Indonesia case. Indonesian Capital Market Review, 9. https://doi.org/10.2139/ssrn.2849726

Winarno, W. W. (2009). Analisis ekonometrika dan statistika dengan EViews (4th ed). UPP 
STIM YKPN.

Wulandari, R. D., \& Erna, H. (2013). Pengaruh environmental performance dan environmental disclosure terhadap economic performance. Jurnal Ekonomi Dan Bisnis Islam, 7(2), 141. https://doi.org/10.25105/jipak.v9i2.4530

Xue, B., Li, P., \& Zhang, Z. (2017). The impact of multi-dimensional environmental performance on firm performance and risk. European Financial Management Association, 1-44. http://www.efmaefm.org/0EFMSYMPOSIUM/2017/papers/EFMA complete paper.pdf

Zeng, H., Zhang, T., Zhou, Z., Zhao, Y., \& Chen, X. (2020). Water disclosure and firm risk: Empirical evidence from highly water-sensitive industries in China. Business Strategy and the Environment, 29(1), 17-38. https://doi.org/10.1002/bse.2347

Zhang, H., Zhang, Z., \& Steklova, E. (2020). Do companies need financial flexibility for sustainable development? Sustainability, 1811. https://doi.org/10.3390/su12051811

Zolfigol, M., \& Zolfigol, M. (2019). Effect of financial flexibility on financial policies of companies listed in Qom Province stock exchange. Research Journal of Management Reviews, 4(1), 10-17. 